\title{
Problems and Needs in English Language Teaching from the Viewpoints of Pre- service English Teachers in Thailand
}

\section{Nutcha Oeamoum ${ }^{1}$ (D) Chuanpit Sriwichai ${ }^{2}$ \\ ${ }_{1,2}^{1, S}$ chool of Liberal Arts, University of Phayao, Thailand. Email:Nutchaoeamoum88@gmail.com Tel:66-951149895 \\ Email:chuanpit.sr@up.ac.th Tel: 66-819523436}

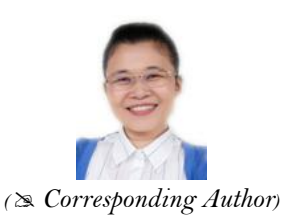

( Corresponding Author)

\begin{abstract}
This study aimed to explore the problems and needs in English language teaching (ELT) of preservice English teachers in Thailand related to three aspects 1) curriculum and content, 2) instructional materials, and 3) teaching methods. The participants were thirty fourth-year preservice English teachers from five universities located in Northern, Central, Northeastern, and Eastern Thailand. The findings from questionnaire and semi-structure interview revealed that the problems and needs in ELT related to curriculum and content were insufficient number of study hours of each English course, inadequate courses for specific English skills, outdated curriculum, and inapplicable content to the real life. Therefore, the participants needed the curriculum focusing on real-world context and communication skills (e.g. speaking and listening skills). The main problems related to instructional materials were non-diverse, insufficient, and ineffective teaching aids, so the participants required teachers to use diverse instructional materials and integrated web-based technology in English classes. Finally, the major problems and needs related to teaching methods included lack of specialists in teaching specific courses and uninteresting teaching technique focusing on lecturing grammar rules and reading rather than practicing communication skills; hence, the pre-service English teachers mainly expressed the needs to learn using games, role play, and oral presentation as these methods were interesting and could increase opportunities to produce target language.
\end{abstract}

Keywords: Problems in ELT, Needs in ELT, Pre-service English teachers, English curriculum and content, English instructional materials, English teaching methods.

Citation | Nutcha Oeamoum; Chuanpit Sriwichai (2020). Problems and Needs in English Language Teaching from the Viewpoints of Pre-service English Teachers in Thailand. Asian Journal of Education and Training, 6(4): 592-601.

History:

Received: 13 July 2020

Revised: 19 August 2020

Revised: 19 August 2020
Accepted: 23 September 2020

Published: 2 October 2020

Licensed: This work is licensed under a Creative Commons Attribution 3.0 License (cc) E

Publisher: Asian Online Journal Publishing Group
Acknowledgement: Both authors contributed to the conception and design of the study.

Funding: This study received no specific financial support.

Competing Interests: The authors declare that they have no conflict of interests.

Transparency: The authors confirm that the manuscript is an honest, accurate, and transparent account of the study was reported; that no vital features of the study have been omitted; and that any discrepancies from the features of the study have been omitted;
study as planned have been explained.

Ethical: This study follows all ethical practices during writing.

\section{Contents}

1. Introduction

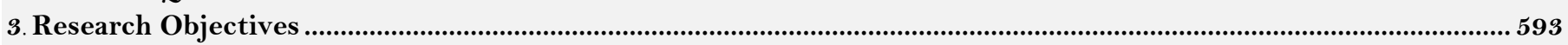

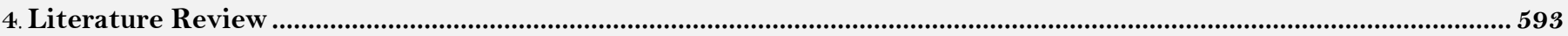

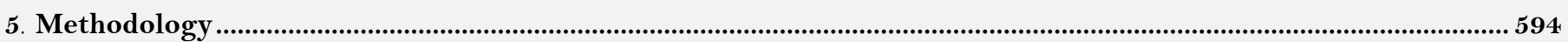

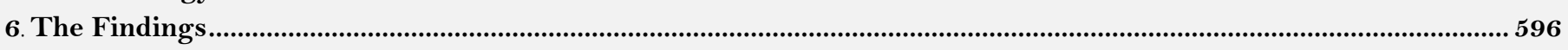

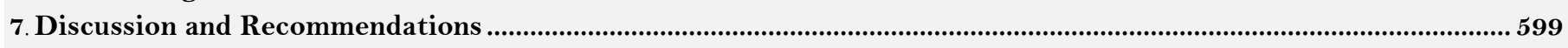

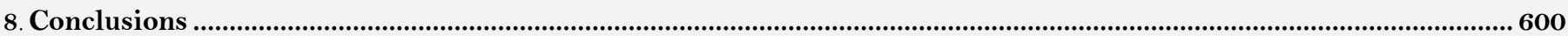

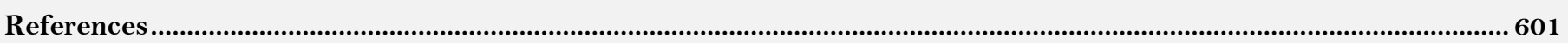




\section{Contribution of this paper to the literature}

This study contributes to existing literature by exploring the problems and needs in English language teaching (ELT) of pre-service English teachers in Thailand related to three aspects 1) curriculum and content, 2) instructional materials, and 3) teaching methods.

\section{Introduction}

In this globalization era, it is undeniable that English is significant as it is used as international language by people all over the world. Similarly, Thai people use English to communicate with others from different countries with different cultural backgrounds. Even though Thai is used as official language in Thailand, English is regarded as the first foreign language that Thai people should learn and practice. English is essential for meaningful interactions in various situation (Kongkerd, 2013). The significance of English could be obviously seen when Thailand joined the ASEAN Economic Community (AEC). Pinyonatthagarn (2016) stated that English proficiency of Thai people has become one of the most important concerns because English has been used as the working language among ASEAN countries. Therefore, English has played influential roles in Thailand.

Realizing the significance of English Ministry of Education has placed English as a compulsory subject for all levels of education in Thailand. English curriculum of Thailand aims to enhance students' interest in language learning, create positive attitude toward English, promote English communication ability (Ministry of Education, 2001). To achieve the ultimate goal of English curriculum, one important movement to produce qualified English teacher is to develop five-year pre-service teacher programs. These programs have been undertaken in Thai universities in order to prepare English teachers who can be effective agent of change in the future (Vibulphol, 2015). The development of English teacher educational program shows an attempt to improve Thai learners' English proficiency.

In Thailand, Klaichim (2009) revealed that the main problems of English teaching and learning for pre-service English teachers included the language skills, learning behaviors, English curriculum and course content, teaching materials, teaching methods, teacher's performance, and institutes support. While Noom-ura (2013) found that preservice teachers mentioned the problems related to curriculum and textbooks, assessment and other factors supporting teaching success. Moreover, they mentioned that the lack of perseverance in practicing or seeking more opportunities to use English contributed to their lack of confidence in using the language for communication. They were aware of continuing professional developments and availability of professional development programs that are relevant to all areas contributing to their career success: their English competencies, and pedagogical strategies for teaching and assessing productive skills, such as listening-speaking, and writing skills.

Additionally, Hill (2014) stated it is important that pre-service teachers obtain appropriate training on how to work well with English language learners. They should be prepared proper education program which better train them with teaching methods and activities. To find the solutions of the problems, satisfy the pre-service English teacher's needs, and provide them suitable program, the systematic study should be conducted to elicit essential information. The results of the study can be used to develop and improve English curriculum and instruction for Thai pre-service English teachers in order to achieve efficacious goals of English teaching and learning in school context. The study will provide understanding of the problems in ELT that pre-service English teachers are facing, and it can be a guideline for policymakers and course designers for designing appropriate English courses and curriculum to prepare productive pre-service English teachers in the future.

\section{Research Questions}

1. What are the problems in English language teaching from the viewpoints of pre-service English teachers in Thailand?

2. What are the needs in English language teaching from the viewpoints of pre-service English teachers in Thailand?

\section{Research Objectives}

1. To explore the problems in English language teaching from the viewpoints of pre-service English teachers in Thailand.

2. To explore the needs in English language teaching from the viewpoints of pre-service English teachers in Thailand.

\section{Literature Review}

\subsection{Pre-Service Teacher Program}

According to Kukari (2003) and Jamjuree (2017) pre-service teacher program is teacher education schemes to prepare student teachers before they become in-service teachers. These pre-service teachers perceived teaching as the transmission of prescribed knowledge from the teacher to students, learning was viewed as the absorption and the memorization of prescribed knowledge, and a teacher's main role was to transmit prescribed knowledge to students. It was perceived that teacher should possess knowledge which is helpful for personal and society's growth. These preconceptions of teaching and learning are often not recognized, confirmation or fully understood by both 
the pre-service teachers who hold them and their students at the beginning of the teacher education program and in the process of learning and teaching. The impact of these preconceptions on the system of learning to teach may not be seen or clearly understood by the pre-service teachers and the lecturers who teach them in their teacher education program. As mentioned above, pre-service teachers are crucial part of education, so it is important that they receive appropriate training on how to work with students.

In Thailand, one way to provide proper preparation for pre-service teachers is to extend the length of their education program. In 2002, the program was expanded from four to five years. In five-year program, the prospective teachers have to spend four years in university for doing course work and another one year in school for practicing teaching (Jamjuree, 2017; Vibulphol, 2015). The curricula of this program aim to produce good teachers in compliance with the standard of Thailand Qualifications Framework for five-year Bachelors of Education Programs and Teacher's Council of Thailand (TCT) Program Accreditation Standards. These two sets of standards require teacher students to gain at least 160 credit hours of four major categories of courses including general education, pedagogical courses, main study courses, and free elective courses. Also, they need to gain firsthand experience in classroom during taking course work, obtain 240 hours of teaching practice in school for one academic year and conduct classroom research during this practicum period, and participate in teachership enhancement activities during five years of study. When pre-service education program meets assessment criteria, the Teachers' Council of Thailand will accredit them, and the graduates can obtain a professional license automatically (TCT, 2014 cited in Vibulphol (2015)).

\subsection{Problems and Needs in English Language Teaching in Thailand}

In terms of pre-service English teachers in Thailand, Klaichim (2009) explored the problems and needs in English Language teaching and learning at the Institutes of Physical Education. The participants were 368 students from 7 fields of study and all 33 English teachers of all the 17 institutes. Student and teacher questionnaires were administered to inquire about the degree of seriousness of problems obstructing English teaching and learning and their needs in English teaching and learning. The results revealed that the very serious problems concerned the students' language skills. In addition, the students and the teachers considered these following problems as moderately serious: students learning behaviors, students language skills, English curriculum, course content, teaching materials, teaching methods, teacher's performance, and institutes support. Both groups identified the needs in the student's preparatory English course, the student's language skills practice, the language activities, the increase of study hours and number of English courses, the provision of teaching aids, the course assessment techniques, and the teacher-training.

Furthermore, Noom-ura (2013) investigated English-teaching problems in Thailand and Thai teacher's professional development needs. This research aimed to explore English-teaching problems related to teachers, students, assessment, curriculum and textbooks, and other factors and also to investigate the needs for the professional development of English language teachers from 77 secondary schools in central Thailand. The result showed that the participating teachers viewed the problems at the moderate level as involving themselves, curriculum and textbooks, assessment and other factors supporting teaching success. The participants reported a high level of problems resulting from students' lack of experience in English and inadequate language background. The students lack of perseverance in practicing or seeking more opportunities to use English also contributed to their lack of confidence in using the language for communication. Although the teachers need of professional development and professional development funds were at a moderate level, they were aware of continuing professional developments and availability of professional development programs. They showed a high level of interest and value to all areas contributing to their career success: their English competencies, and pedagogical strategies for teaching and assessing productive skills, such as listening-speaking, and writing skills.

\section{Methodology}

\subsection{Research Design}

This study utilized quantitative and qualitative approaches. The questionnaires were administered to collecting quantitative data, then the semi-structured interviews were undertaken to elicit the qualitative data.

\subsection{Participants}

The participants of the study were 30 fourth-year pre-service English teachers from five universities located in Northern, Central, Northeastern, and Eastern regions of Thailand. They were selected by using snowball technique. At first, the researcher identified potential participants who were pre-service English teachers of the University of Phayao and knew pre-service English teachers from other universities. Next, those participants were asked to recruit other pre-service English teachers from other universities to participate in the study.

\subsection{Research Instruments}

There were 2 research instruments that used in this study:

1. Questionnaire 
The questionnaire was adapted from the study of Klaichim (2009). It was divided into 3 parts. Part one was about demographic data of the participants. In part two, five-point rating scale was employed ( $1=$ strongly disagree, $5=$ strongly agree) to elicit participants' problems in English teaching and learning in three aspects: curriculum and content, instructional materials, and teaching methods. For part three, ranking scales were used to require the participants to express their needs in four dimensions: English curriculum and content, instructional materials, teaching methods, and assessment techniques.

\section{Semi-structure interview questions}

The semi-structured interview was employed to collect qualitative data from the participants. The interview consisted of three parts. Part one was about demographic data of the participants. Part two was used to ask about the problems in English teaching and learning in three aspects, and part three asked about their needs in English teaching and learning in four aspects. The investigated dimensions in the interview were in congruence with those in the questionnaire.

\subsection{Research Instrument Validity and Reliability}

\subsubsection{The Questionnaire}

The questionnaire was evaluated by 3 experts using Index of Item - Objective Congruence (IOC), and the IOC score was at 1.00. Then it was tried out with 10 Thai pre-service English teachers from the University of Phayao to calculate reliability using Cronbach's Alpha Coefficient, and the scores was at 0.71. According to Tavakol and Dennick (2011) acceptable values of alpha range from 0.70 to 0.95. The Cronbach's Alpha Coefficient value of the questionnaire, hence, was appropriate.

\subsubsection{The Semi-Structure Interview Questions}

The interview questions were evaluated by 3 experts using Index of Item - Objective Congruence (IOC), and they gained the score at 1.00 .

\subsection{Data Collection}

The data were collected during the $2^{\text {nd }}$ semester of academic year 2019. The researcher contacted fourth-year pre-service English teachers of five universities located in Northern, Central, Northeastern, and Eastern Thailand and asked for help in distributing and collecting the questionnaires. Then, the researcher interviewed the interviewees who voluntarily participated from five universities by using web-based application and face-to-face interview.

\subsection{Data Analysis}

The participants' demographic data from part one of the questionnaire were analyzed using percentage. The data of problems in English teaching and learning from part two of the questionnaire were studied using mean and standard deviation. The interpretation of mean score of the participants' problems was as follows (Prachanant, 2012):
4.50 - 5.00 means the highest problem
3.50 - 4.49 means high problem
2.50 - 3.49 means moderate problem
$1.50-2.49$ means low problem
$1.00-1.49$ means the lowest problem

For the data of the participants' needs from part three, mean and standard deviation was used to analyzed, the criteria for interpretation was as follows (Prachanant, 2012):

$$
\begin{aligned}
& 4.50-5.00 \text { means the highest need } \\
& 3.50-4.49 \text { means high need } \\
& 2.50-3.49 \text { means moderate need } \\
& 1.50-2.49 \text { means low need } \\
& 1.00-1.49 \text { means the lowest need }
\end{aligned}
$$

The data obtained from the interviews were analyzed by content analysis following this procedure: the researcher read all of the answers, coded them by the keywords found in the answers, and finally figured out the frequencies of each category.

\subsection{Ethical Approval}

The researchers contacted the participants one-by-one three weeks prior to the distribution of the questionnaire to introduce themselves, inform the objectives, provide any information required by the participants. Also, the participants were asked for the permission of the data collection and interview. An appointment was made beforehand with the participants who were able to attend the interview. The questionnaire data and the transcripts 
of the interview data were kept securely for a period of three years in the cabinet and on the computer requiring password to login.

\section{The Findings}

\subsection{Demographic Data of the Participants}

The participants' demographic information was presented in the following table:

Table-1. Demographic data of the participants.

\begin{tabular}{l|c|c}
\hline Background & Number & Percent \\
\hline Gender & & \\
\hline Male & 8 & $26.7 \%$ \\
\hline Female & 22 & $73.3 \%$ \\
\hline Total & 30 & $100 \%$ \\
\hline University & 13 & \\
\hline University of Phayao & 5 & $43.3 \%$ \\
\hline Phranakhon Rajabhat University & 4 & $16.6 \%$ \\
\hline Thepsatri Rajabhat University & 4 & $13.3 \%$ \\
\hline Nakhon Ratchasima Rajabhat University & 2 & $6.6 \%$ \\
\hline Nakhonsawan Rajabhat University & 2 & $6.6 \%$ \\
\hline Rambhai Barni Rajabhat University & 30 & $100 \%$ \\
\hline Total & &
\end{tabular}

Based on Table 1, the demographic data of 30 participants were classified by gender and university. In term of genders, 22 respondents $(73.3 \%$ ) were female and eight respondents (26.7\%) were male. Regarding their universities, 13 students (43.3 \%) were studying at the University of Phayao. Five of them (16.6 \%) were Phranakhon Rajabhat University's students. Four students (13.3\%) were from Thepsatri Rajabhat University while four students (13.3\%) were studying at Nakhon Ratchasima Rajabhat University. Other four students were from Nakhonsawan Rajabhat University (6.6 \%) and Rambhai Barni Rajabhat University (6.6 \%).

\subsection{Problems in English Language Teaching of Pre-Service English Teachers}

This section reported the findings of the questionnaire and the interview analysis of problems in learning English of pre-service English teachers in three aspects; English curriculum and content, instructional materials, and teaching methods.

\subsubsection{The Data of Problems in English Language Teaching of Pre-Service English Teachers from the Questionnaire \\ 6.2. 1.1. Problems in English Language Teaching Related to English Curriculum and Content}

The results of the problems of English curriculum and content based on the questionnaire were presented as follows:

Table-2. The problems related to English curriculum and content

\begin{tabular}{c|l|c|c|c}
\hline No & Problem & $\overline{\overline{\boldsymbol{x}}}$ & SD & Meaning \\
\hline 1 & Courses for pre-service English teachers are not interesting. & 3.56 & 1.13 & High problem \\
\hline 2 & $\begin{array}{l}\text { The number of compulsory English courses for pre-service } \\
\text { English teachers is insufficient. }\end{array}$ & 3.46 & 1.14 & $\begin{array}{c}\text { Moderate } \\
\text { problem }\end{array}$ \\
\hline 3 & $\begin{array}{l}\text { The number of hours for each English course for pre-service } \\
\text { English teachers is insufficient. }\end{array}$ & 3.66 & 1.06 & High problem \\
\hline 4 & Contents in the textbook used cannot be applied in real life. & 3.60 & 1.19 & High problem \\
\hline 5 & $\begin{array}{l}\text { There are not enough specific English courses for each skill } \\
\text { (Listening, Speaking, Reading, and writing) for pre-service } \\
\text { English teachers. }\end{array}$ & 3.63 & 1.27 & High problem \\
\hline 6 & $\begin{array}{l}\text { There are not enough elective courses that suit pre-service } \\
\text { English teachers' interest. }\end{array}$ & 3.30 & 1.05 & $\begin{array}{c}\text { Moderate } \\
\text { problem }\end{array}$ \\
\hline
\end{tabular}

Table 2 showed the problems in English teaching and learning related to curriculum and content. According to the table, it can be seen that the insufficient number of hours for each English course was the highest problem for pre-service English teachers $(\overline{\boldsymbol{x}}=3.66$ ), followed by not enough specific English courses for each skill (Listening, Speaking, Reading, and writing) $(\overline{\boldsymbol{x}}=3.63)$, inapplicable contents in the textbook $(\overline{\boldsymbol{x}}=3.60)$, uninteresting courses $(\overline{\boldsymbol{x}}=$ 3.56), not enough compulsory English courses $(\overline{\boldsymbol{x}}=3.46)$. There are not enough elective courses that suit pre-service English teachers' interest (item 6) was rated at the lowest mean $(\overline{\boldsymbol{x}}=3.30)$. 
6.2.1.2. Problems in English Language Teaching Related to Instructional Materials

The results of the problems of instructional materials based on the questionnaire were presented below:

Table-3. The problems analysis of instructional materials.

\begin{tabular}{c|l|c|c|c}
\hline No & Problem & $\overline{\boldsymbol{x}}$ & SD & Meaning \\
\hline 1 & English textbooks and learning materials are insufficient. & 3.30 & 0.99 & Moderate problem \\
\hline 2 & $\begin{array}{l}\text { Visual aids (e.g. TV, computers, audio clips, projectors and screens) } \\
\text { are insufficient. }\end{array}$ & 3.33 & 1.06 & Moderate problem \\
\hline 3 & $\begin{array}{l}\text { Visual aids (e.g. TV, computers, audio clips, projectors and screens) } \\
\text { are not effective. }\end{array}$ & 3.27 & 0.98 & Moderate problem \\
\hline 4 & $\begin{array}{l}\text { There are not enough opportunities to use the language } \\
\text { laboratory. }\end{array}$ & 3.30 & 1.19 & Moderate problem \\
\hline 5 & Language laboratories are insufficient. & 3.20 & 1.17 & Moderate problem \\
\hline 6 & Instructional materials are not diverse. & 3.47 & 0.90 & Moderate problem \\
\hline
\end{tabular}

Table 3 demonstrated problems of instructional materials. All items were at moderate level.

The results from the questionnaires showed that item 6 "Instructional materials are not diverse" was rated highest $(\overline{\boldsymbol{x}}=3.47$ ). The second highest mean was item 2 "Visual aids (e.g. TV, computers, audio clips, projectors and screens) are insufficient $(\overline{\boldsymbol{x}}=3.33)$ ". The lowest mean was item 5 "Language laboratories are insufficient" $(\overline{\boldsymbol{x}}=3.20)$, and the second lowest mean was item 3 "Visual aids (e.g. TV, computers, audio clips, projectors and screens) are not effective" $(\overline{\boldsymbol{x}}=3.27)$.

\subsubsection{Problems in English Language Teaching Related to Teaching Methods}

The results of the problems related to teaching methods based on the questionnaire were presented below:

Table-4. The problems analysis of teaching methods

\begin{tabular}{l|l|l|l|l}
\hline No & Problem & $\overline{\boldsymbol{X}}$ & SD & Meaning \\
\hline 1 & There are not enough specialists in teaching English courses. & 4.03 & 1.13 & high problem \\
\hline 2 & $\begin{array}{l}\text { Teaching aids (pictures, authentic materials, CDs, etc.) for teaching } \\
\text { pre-service English teachers are not interesting. }\end{array}$ & 3.63 & 1.07 & high problem \\
\hline 3 & $\begin{array}{l}\text { Teaching techniques for pre-service English teachers are not } \\
\text { interesting. }\end{array}$ & 3.67 & 1.06 & high problem \\
\hline 4 & $\begin{array}{l}\text { Teaching techniques for pre-service English teachers are not } \\
\text { diverse. }\end{array}$ & 3.60 & 1.07 & high problem \\
\hline 5 & $\begin{array}{l}\text { There are not enough techniques for teaching pre-service English } \\
\text { teacher in each skill (Listening, Speaking, Reading, and writing) }\end{array}$ & 3.63 & 1.19 & high problem \\
\hline 6 & There is more emphasis on books than practice. & 3.50 & 1.20 & high problem \\
\hline
\end{tabular}

As seen in Table 4, the all items of problems in the aspect of teaching method gained high mean scores. The highest mean was item 1 "There are not enough specialists in teaching English courses" $(\overline{\boldsymbol{x}}=4.03)$. Item 3 "Teaching techniques for pre-service English teachers are not interesting" obtained the second highest mean $(\overline{\boldsymbol{x}}=3.67)$. The lowest mean score was item 6 "There is more emphasis on books than practice" $(\overline{\boldsymbol{x}}=3.50)$.

\subsubsection{The Data of Problems in English Language Teaching of Pre-Service English Teachers from the Interviews}

This part was elicited from 5 interviewees who were $4^{\text {th }}$ years pre-service English teachers of five universities located in Northern, Central, Northeastern, and Eastern Thailand. The data were classified into 3 sections corresponding to 3 aspects in the questionnaire and described as follows:

\subsubsection{Problems in English Language Teaching Related to English Curriculum and Content}

The findings from the interviews revealed that English curriculum and content for teaching pre-service English teachers were difficult, incomprehensive, and out of date. Apart from that the number of hours for each English course for pre-service English teachers was not sufficient. It was noted:

"The English curriculum is not up to date. Also, vocabulary and grammar structures in some units are too difficult."

"The content is incomprehensive and difficult for students"

"The number of hours for each English course for pre-service English teachers is not enough"

\subsubsection{Problems in English Language Teaching Related to Instructional Materials}

The students mentioned about ineffective and insufficient instructional materials. One of them mentioned:

"Problems of instructional materials is that teaching aids are not available and insufficient. It makes learning more difficult to learn"

There are not enough teaching aids, and some existing aids broke down, so teaching is not interesting." 
6.2.2.3. Problems in Learning English Related to Teaching Methods

The participants stated in the interview that class instruction focused on lecturing content rather than practicing language skills, so they had problems in communication, especially listening and speaking. They also reported that teachers lacked some English skill. They reported:

"Teachers teach the rules of grammar rather than let us practice English skills."

"Teaching frequently focuses on reading and writing not speaking and listening, so I can't speak and listen English well when I meet foreigners in real life",

"Teachers use old-fashioned teaching methods that focus on lectures, not speaking and listening, so I cannot speak English in my daily life."

"Sometimes, teachers mispronounce some words. This makes students misunderstand the meanings, so teacher should be specialized in English language."

\subsection{The Needs in English Language Teaching of Pre-Service English Teachers}

This section reported findings from the questionnaire and interviews of the needs in learning English of preservice English teachers in four aspects including English curriculum and content, instructional materials teaching methods, and assessment technique.

\subsubsection{The Findings of the Needs in English Language Teaching of Pre-Service English Teachers from the Questionnaire \\ 6.3.1.1. The Needs in English Language Teaching Related to English Curriculum and Content}

The results of the needs of English curriculum and content based on the questionnaire were as follows:

Table-5. The need analysis of English curriculum and content.

\begin{tabular}{c|c|c|c|l}
\hline No & Need & $\overline{\boldsymbol{x}}$ & SD & Meaning \\
\hline 1 & Listening & 3.10 & 1.52 & Moderate need \\
\hline 2 & Speaking & 3.17 & 1.49 & Moderate need \\
\hline 3 & Reading & 2.93 & 1.11 & Moderate need \\
\hline 4 & Writing & 2.67 & 1.37 & Moderate need \\
\hline 5 & Translation & 2.67 & 1.47 & Moderate need \\
\hline
\end{tabular}

Table 5 showed that the needs related to English curriculum and content for teaching five kinds of English skills namely listening, speaking, reading, writing, and, translation were at moderate scale. The participants rated the need of curriculum and content for speaking skill most $(\overline{\boldsymbol{x}}=3.17)$, followed by listening $(\overline{\boldsymbol{x}}=3.10)$, reading $(\overline{\boldsymbol{x}}=$ 2.93), writing $(\overline{\boldsymbol{x}}=2.67)$ and translation skills $(\overline{\boldsymbol{x}}=2.67)$

6.3.1.2. The Needs in English Language Teaching Related to Instructional Materials

The results of the needs of instructional materials based on the questionnaire were presented as follows:

Table-6. The need analysis of instructional materials

\begin{tabular}{l|l|l|l}
\hline Need & $\overline{\boldsymbol{x}}$ & SD & Meaning \\
\hline Audio-visual aids (TV, DVD players, CDs) & 2.90 & 1.27 & moderate need \\
\hline Fully-equipped language laboratory & 3.03 & 1.33 & moderate need \\
\hline Prescribed textbooks for specific disciplines & 2.77 & 1.25 & moderate need \\
\hline Cable TV & 2.93 & 1.26 & moderate need \\
\hline Web Based Application (Online learning platform, Facebook, YouTube, Google) & 3.30 & 1.44 & moderate need \\
\hline
\end{tabular}

According to Table 6, the needs of pre-service English teachers concerning the instructional materials were at a moderate level. It can be seen that Web Based Application was the highest need for the participants $(\overline{\boldsymbol{x}}=3.30)$, followed by fully-equipped language laboratory $(\overline{\boldsymbol{x}}=3.03)$, cable TV $(\overline{\boldsymbol{x}}=2.93)$, audio-visual aids $(\overline{\boldsymbol{x}}=2.90)$ and prescribed textbooks for specific disciplines $(\overline{\boldsymbol{x}}=2.77)$ respectively.

\subsubsection{The Needs in English Language Teaching Related to Teaching Methods}

The results of the needs of teaching methods based on the questionnaire were presented below:

Based on Table 7, the needs of language games, role-playing, oral presentation, and group discussion were at highest level. However, the needs of using debate, making bulletin boards of English, producing English newsletters, broadcasting in English within the university, English signing contest, and English skills competitions were at high scale. The needs of using role-playing as a teaching method were the highest $(\overline{\boldsymbol{x}}=4.77)$. The second and third highest teaching method needed were group discussion $(\overline{\boldsymbol{x}}=4.67)$ and oral presentation $(\overline{\boldsymbol{x}}=$ 4.63), respectively. The needs of broadcasting in English within the university was rated lowest $(\overline{\boldsymbol{x}}=3.87)$. 
Table-7. The need analysis of teaching methods.

\begin{tabular}{l|l|l|l|l}
\hline NO & Need & $\overline{\boldsymbol{x}}$ & SD & Meaning \\
\hline 1 & Language games & 4.53 & 3.36 & the highest need \\
\hline 2 & Role-playing & 4.77 & 3.44 & the highest need \\
\hline 3 & Oral presentation & 4.63 & 2.72 & the highest need \\
\hline 4 & Group discussion & 4.67 & 2.69 & the highest need \\
\hline 5 & Debate & 4.40 & 2.68 & high need \\
\hline 6 & Making bulletin boards of English & 3.90 & 2.63 & high need \\
\hline 7 & Producing English newsletters & 4.00 & 2.49 & high need \\
\hline 8 & Broadcasting in English within the university & 3.87 & 2.33 & high need \\
\hline 9 & English singing contest & 3.93 & 2.45 & high need \\
\hline 10 & English skills competitions & 4.47 & 2.97 & high need \\
\hline
\end{tabular}

6.3.2. The Findings of the Needs in English Language Teaching of Pre-Service English Teachers from the Interviews

The data from the interview were classified into three sections corresponding to three aspects in the questionnaire and described as follows:

\subsubsection{The Needs in English Language Teaching Related to English Curriculum and Content}

The findings of the interview showed that pre-service English teacher needed curriculum and content for learning speaking, listening and vocabulary. It was noted:

"The curriculum should have more courses for listening and speaking skills to train students for communication in real life."

"The vocabulary used in daily communication should be added to the content of English subjects."

"I want to learn more vocabulary."

6.3.2.2. The Needs in English Language Teaching Related to Instructional Materials

The interviewees mentioned that they wanted to learn through various and modern teaching materials. It was revealed:

"The teachers should use various teaching materials to make the class more interesting and effective learning, such as videos, worksheets, word cards, picture cards, and internet-based technology."

"I want to learn by using authentic materials such as newspaper, posters, VDO clip, simulations, modern technology."

\subsubsection{The Needs in English Language Teaching Related to Teaching Methods}

The participants mentioned about role-play, games and interviewing activity. It was noted:

"I want teaching activities that promote interaction and speaking skills such as role playing, games and interview."

"I think role-play and games are the interesting teaching methods, but actually every activity has both advantages and disadvantages. It is based on the course and how the teacher will apply it."

"I like interviewing activity because I think it is necessary in real life"

\section{Discussion and Recommendations}

\subsection{Problems and Needs in English Language Teaching of Pre-Service English Teachers Related to English} Curriculum and Content

The findings disclosed the problems in teaching and learning English of pre-service English teachers related to English curriculum and content were at a high level. The participants rated the insufficient number of hours for each English course was the highest problem for pre-service English teachers, followed by inadequacy of specific English courses for each skill (Listening, Speaking, Reading, and writing), and the content in course book could not be applied to real-world context. These findings were similar to those of the interviews. It was mentioned that the number of learning hours in each English course is not sufficient. Moreover, the interviewees stated the curriculum was out of date, some parts of content were too difficult.

The problems agreed with the needs related to English curriculum and content. The results of the questionnaire for need analysis showed that pre-service English teachers wanted the curriculum focusing on speaking and listening skills most. In the same way, the interview findings indicated that the interviewees needed curriculum providing them more opportunities to practice using English in speaking and listening. Also, they requested learning vocabulary used in real life. It could be seen that pre-service English teachers put emphasis on learning and practicing communication skills rather than grammar structures and reading. Although they are going to be the teachers who is knowledge agent of English in the future, they did not need to be expert in grammar rules and vocabulary only, but they also needed to be skillful in producing and listening target language. The findings were in congruence with the study of Noom-ura (2013). The previous study found that English teachers of primary schools in central Thailand needed to improve their communication skills, and they were not 
satisfied to their abilities to speak and listen to English. Teachers realized the importance of teaching listening and speaking as productive skills, and English teachers had a desire to take training courses the promote their English proficiency. Furthermore, Klaichim (2009) revealed students and teachers at institution of Physical Education needed more learning hours for compulsory English subjects. They believed that the students would gain more knowledge. Also, they requested English courses for enhancing particular English skills.

\subsection{Problems and Needs English Language Teaching of Pre-Service English Teachers Related to English Instructional Materials}

Regarding problems in English language teaching related to instructional materials, the highest problem identified in the questionnaire was the lack of diversity of instructional materials and insufficient visual aids. Likewise, the interviewees mentioned existing instructional materials were ineffective and insufficient. When looked at need analysis, web-based application was the highest need for the questionnaire respondents, and the interviewees told that they wanted the teachers to use diverse and modern teaching aids such as educational websites and platforms. This indicated that the pre-service English teachers had a desire to learn by using internetbased technology in English classes. Incorporating information communication technology into English classroom is inevitable feature of teaching and learning in $21^{\text {st }}$ century, because technology can help improve learners' language skills. According to Jacqui (2015) technology enables learners to be independent in learning, and it deepens learning because resources that learners are interested in are utilized. Adipat, Thumvichit, Petchprasert, and Iamsirirak (2019) found that the pre-service and in-service English teachers needed learning through technology as it was an essential tool for language learning.

\subsection{Problems and Needs in English Language Teaching of Pre-Service English Teachers Related to Teaching Methods}

In terms of problems in English language teaching related to teaching methods, all items in this category were at a high level. The item with the problems of insufficiency of specialists in teaching English was responded highest, followed by the item with problem of employing uninteresting teaching techniques. The results of the questionnaire were supported by the findings of the interview. The participants unveiled the instructors emphasized on grammar rules, reading, and writing skills and mostly carried out class by lecturing rather than having students to practice communicative skills. All of these led to inability of English communication of real life. The needs related to teaching methods were in line with the problems they were confronting. Based on the questionnaire, the pre-service English teachers needed to learn through game, role play, oral presentation, and discussion most. Similarly, it was mentioned in the interview that teaching methods that the participants wanted were role-play and games because these methods were interesting. The findings were in consistence with the study of Adipat et al. (2019). In the previous study, pre-service English teachers told that their English classes focused on teaching grammar structures and vocabulary. They were not given chances to produce and use English in real-world contexts, and it was stated that they needed skillful and knowledgeable English instructors. Furthermore, Klaichim (2009) found that English teachers should be specialized in teaching specific English skills. Moreover, Rayan (2016) suggested that the students needed role-plays, games, songs, multimedia, and information technology in class because these teaching techniques, especially role-plays, games, and songs were fun and easily attracted student's attention. These teaching methods could promote communication in a natural way because role-plays require interaction and commutainment (communication through entertainment) activities among characters.

This study surveyed the problems and needs in teaching and learning English of pre-service English teachers from thirty respondents of the questionnaire and five interviewees. The further study should extend the scale of the study by recruiting more participants in order to deepen understanding about problems and real needs of preservice English teachers in Thailand. In addition, the presents study identified the problems and needs of the preservice English teachers. The further study should investigate the existing curriculum, teaching aids and materials to find the gaps between the learners' needs and current situation. With the findings of that research, the policy makers, curriculum designers, and educators will be able to design the curriculum that appropriately and effectively satisfy the learners' needs and meet the requirement of the real-world market.

\section{Conclusions}

The analysis of quantitative and qualitative data disclosed the problems and needs in ELT related to curriculum and content were insufficient study hours of each English course, inadequate courses for specific English skills, out-of-date curriculum, and inapplicable content to the real-world communication. Thus, the curriculum focusing on real life context and communication skills were needed. The main problems related to instructional materials were non-diverse, insufficient, and ineffective teaching materials, so the use of diverse instructional materials and integrated web-based technology in English classes was requested. The major problems and needs related to teaching methods included the shortage of experts in teaching specific courses and uninteresting teaching technique focusing on lecturing grammar structures and reading rather than practicing communication skills. Therefore, the needs to learn using games, role play, and oral presentation were mentioned because these methods were interesting and could increase opportunities to produce target language. 


\section{References}

Adipat, S., Thumvichit, A., Petchprasert, A., \& Iamsirirak, E. (2019). Needs and expectations for an ELT master's program in Thailand: Voices from pre- and in-service teachers. Kasetsart Educational Review, 34(1), 10-20.

Hill, A. (2014). Preparing pre-service teachers to work with English language learners. Honors Theses. Retrieved from https://ecommons.udayton.edu/uhp_theses/.

Jacqui, M. (2015). 13 reasons for using technology in the classroom. Retrieved from: https://jacquimurray.net/2014/02/19/13-reasons-forand-3-against-technology-in-the-classroom/.

Jamjuree, D. (2017). Teacher training and development in Thailand. Journal of Research and Curriculum Development, 7(2), 7-19.

Klaichim, S. (2009). Problems and needs in English language teaching and learning at the institutes of physical education. Unpublished Master's Thesis. Prince of Songkla University, Songkla, Thailand.

Kongkerd, W. (2013). Teaching English in the era of English used as a lingua Franca in Thailand. Executive Journal, 33(4), 3-12.

Kukari, J. A. (2003). Preconceptions of teaching and learning of three secondary school pre service teachers in Papua New Guinea Papua New Guinea. Journal of Education, 5(1), 43-55.

Ministry of Education. (2001). The basic education curriculum B.E. 2544 (A.D. 2001). Bangkok: The Express Transportation Organization of Thailand (ETO).

Noom-ura, S. (2013). English teaching problems in Thailand and Thai teachers professional development needs. English Language Teaching, 6(11), 139-147. Available at: http://dx.doi.org/10.5539/elt.v6n11p139.

Pinyonatthagarn, D. (2016). ASEAN community and Thailand's need for English proficiency for better Job opportunities. Paper presented at the 4th Rajabhat University National and International Research and Academic Conference, Burirum, Thailand.

Prachanant, N. (2012). Needs analysis on English language use in tourism industry. Procedia-Social and Behavioral Sciences, 66, 117-125. Available at: https://doi.org/10.1016/j.sbspro.2012.11.253.

Rayan, A. (2016). What are their characteristics of a successful teacher of English? Retrieved from: https://www.teachingenglish.org.uk/blogs/albertrayan/characteristics-highly-effective-teachers-english.

Tavakol, M., \& Dennick, R. (2011). Making sense of Cronbach's Alpha. International Journal of Medical Education, 201 1(2), 53-55.

Vibulphol, J. (2015). Thai teacher education for the future: Opportunities and challenges. Journal of Education Studies, 43(3), 50-64. 